\title{
Ideology and Translation: A Critical Discourse Analysis Approach towards the Representation of Political News in Translation
}

\author{
Mahdi Aslani (Corresponding Author) \\ Department of English, East Azarbaijan Science and Research Branch, Islamic Azad University, Tabriz, Iran \\ E-mail: M.Aslani64@gmail.com \\ Bahloul Salmani \\ Department of English, East Azarbaijan Science and Research Branch, Islamic Azad University, Tabriz, Iran \\ E-mail: Salmani_B@yahoo.com
}

Received: 03-09- 2014

Published: 01-05- 2015
Accepted: 07-12- 2014

doi:10.7575/aiac.ijalel.v.4n.3p.80
Advance Access Published: December 2014

URL: http://dx.doi.org/10.7575/aiac.ijalel.v.4n.3p.80

\begin{abstract}
Recently the impact of ideology of the powerful agents namely- Political Parties, News Agencies and even the translators- on the translation has been considered significantly among the translation scholars. This study investigates the role of ideology in translating news media. To this end, we utilize Norman Fairclough's assumptions in critical discourse analysis, claiming that "ideologies reside in texts" that "it is not possible to read off' ideologies from texts" and that "texts are open to diverse interpretations" (Fairclough, 1995a) It also follows Lefevere's (1992a, 1992b) Patronage theory. In this paper, we will compare the news texts with their translations in order to reveal the role of ideology in the translation process.
\end{abstract}

Keywords: Ideology, Critical Discourse Analysis, Patronage

\section{Introduction}

\subsection{Media}

With the advancement of technology, media as the most important element of mass communication has taken an important place. Malkawi (2012) quite rightly states that:

Media text functions as a window through which we can view the world and live the events as real. It has the power to influence readers by all means since it is an effective mechanism for affecting individual perceptions of reality. By analyzing the media text ideologically, we are able to see the debates in society through text. (p. 22)

As Croteau and Hoynes (2003) confirm, it "allows us to see what kinds of ideas circulate through media texts, how they are constructed, how they change over time, and when they are being challenged" (p. 163). To put it another way, there is a close relationship between media and ideology. In this regard, Malkawi (2012) argues that:

Ideology is the invisible power produced and perpetuated in the machinery of media as discourse that forces language to take a special subjective turn in order to serve the ideological interest of the powers that be. It exists in the media output or 'products'. (pp. 21,22)

Croteau and Hoynes (2003) further observe that there have been several scholarly findings that explored the ways in which the news media produce an ideological vision of the world. The first finding is that news media reflects the ideas of the institutions which provide their interests. The second finding is that "news reaffirms the basic social order and the values and assumptions it is based on" (p. 169). Connected to this, Fairclough (1995b) also confirms this relationship when he defines media as the power "to shape governments and parties (...) the power to influence knowledge, beliefs, values, social relations, and social identities. A signifying power (the power to represent things in particular ways) is largely a matter of how language is use". He concludes that media output is "shaped by ideology and media texts may be said to function ideologically. Therefore, they contribute to reproducing social relations of domination and exploitation" (Fairclough 1995b, pp.2-44). In this light, it can be argued that "media communicates through the discourse as its own communicative vehicle, its own view of social reality, and, thus, influences the mind of others" (Malkawi, 2012, p. 22).

\section{Literature Review}

\subsection{Media and translation}

Media change the way societies communicate - and thus how culture is shaped- in a variety of ways. Perhaps technology has the most fundamental influence to create and distribute symbols (Hallaban, 1997 p. 10). Technology has 
made the media the most important immediate influence on opinions and understanding in the industrialized world and has significantly heightened media impact in the developing countries as well. Media have a powerful capacity to encourage global awareness thereby promoting cross-cultural understanding, tolerance and acceptance of ethnic, cultural, religious and gender differences in communities across the globe. Croteau and Hoynes (2003) state that:

Virtually all forms of mass media - radio, television, movies, music, and the Internet - are standard targets, attacked by politicians from different political perspectives selling certain messages and worldviews. Thus, mass media can be understood in ideological terms, as forms of communication that privilege certain sets of ideas and neglect or undermine others. Therefore, Media are, without doubt, agents of the powerful, and, the ideas of the powerful are imposed on readers or viewers. Media are cultural sites where the ideas of the powerful are circulated and where they can be contested. (Croteau and Hoynes, 2003, p. 161)

Translation and the mass media have similar characteristics since they are both instruments of communication. According to Hatim and Mason (1997), translation is: an act of communication which attempts to relay, across cultural and linguistic boundaries, another act of communication which may have been intended for different purposes and different readers or hearers (p. 1). Translation can be defined and categorized very differently. Traditional, natural equivalence theories "adopt a narrower perspective on translation as substitution of concrete source text segments with target language segments of the same value" (Pym, 2010, p. 7). In contrast to this, translation is also defined in very broad terms, as expressed by Steiner's $(2004$, p. 1$)$ viewpoint that "every language act is actually a translation".

In today's globalization and particularly regarding to the news media, translation is becoming increasingly important. News actually is the product of powerful agents According to Darwish (2006, p. 54) translators and or translationjournalists work under the powerful agents who impose their ideas on their audience specially regarding to news media translation.

\subsection{Ideology and Translation}

The exercise of ideology in translation is as old as the history of translation itself (Karoubi, 2005). According to Fawcett (1998), "throughout the centuries, individuals and institutions applied their particular beliefs to the production of certain effect in translation". He claims that "an ideological approach to translation can be found in some of the earliest examples of translation known to us" (Fawcett, 1998, pp. 106-107). Lefevere (1992b) states that "translation is a rewriting of an original text which reflects a certain ideology and a poetics and as such manipulate literature to function in a given society in a given way" (Lefevere, 1992b, p. vii). For Hatim and Mason (1997) ideology encompasses "the tacit assumptions, beliefs, and value systems which are shared collectively by social group". They make a distinction between 'the ideology of translation' and 'the translation of ideology'. Whereas the former refers to the basic orientation chosen by the translator operating within a social and cultural context, and the later refers to the extent of mediation supplied by a translator of sensitive texts. 'Mediation' is defined as "the extent to which translators intervene in transfer process, feeding their own knowledge and beliefs into processing the text" (Hatim and Mason, 1997, as cited in Hatim and Munday, 2004, pp.102-103).Therefor, it can be said that there is a close relationship between ideology and translation. In other words any translation is Ideological since it is represented via the objectives of a social group. Similarly, Schäffner (2003) claims that all translations are ideological since "the choice of a source text and the use to which the subsequent target text is put are determined by the interests, aims, and objectives of social agents" (p. 23).

\subsection{Translation as Rewriting or Manipulation}

Translation studies have set foot in many different areas up to now. As the linguistic-oriented studies of translation have declined, the cultural-oriented descriptive approach has been prominent over the past decades. The descriptive approach has its origin in comparative literature and Russian Formalism. The idea of literary polysystem shows that different literatures and genres, including translated and non-translated works, compete for dominance (Zhang, 2012, p. 754). André Lefevere (1946-1996) moved away from polysystem terminology to examine translation as "rewriting". Lefevere dismisses the kinds of linguistic theories of translation, which "have moved from word to text as a unit, but not beyond" (Lefevere, 1992b, p.87) without considering the text in its cultural environment. Instead he goes beyond the limitation of language and focuses on the interaction between translation and culture. The kennel of Lefevere's translation theory is the theory of manipulation or rewriting. According to him, any work is not translated in vacuum, which is certainly manipulated or rewritten in a certain form for a certain reason (Lefevere, 1992a, p. 14, as cited in Zhang, 2012, p. 754). In addition, he introduced the concept of patronage, which also plays an important part in the translation. According to Shuping (2013) scholars of manipulation school argue that translation has always been conducted under special purposes. He states that:

Translation is always shaped by a certain force, power and so on, and the choice of the works to be translated, and goals of the translation activity are also set by certain forces. Therefore, translation takes the forms of rewriting, since it is performed under certain constraints and for certain purposes. (Shuping, 2013, p. 56)

\subsection{An Overview of Critical Discourse Analysis (CDA)}

Critical Discourse Analysis stems from a critical theory of language, which regards the use of language "as a form of social practice" (Fairclough and Wodak, 1997, p. 258) and considers more on the context of language use to be important. In fact, it is a sort of discourse that does not consider language use free from ideological perspectives. "It is," generally speaking, "a study of the relations between discourse, power, dominance, social inequality and the position of the discourse analyst in such social relationships" The notions of "ideology, power, hierarchy and gender together with sociological variables were all seen as relevant for an interpretation or explanation of text" (Van Djik, 1993, p. 283).It is 
generally believed that CDA is not a single method but is rather an approach, which consists of different perspectives and different methods for studying the relationship between language use and social context (Wang, 2006, p. 60). Richardson (2007) believes that "CDA is a perspective on critical scholarship: a theory and a method of analyzing the way that individuals and institutions use language". Critical Discourse Analysts focus on "social problem and especially the role of discourse in the production and reproduction of power abuse or dominance" (Van Dijk, 2001, p. 96; Richardson, 2007, p.1). Fiske (1994) states that our words are never neutral they carry power that reflects interest of speakers. In fact CDA is a framework which unwraps ideological insights behind the linguistic units.

\subsection{Critical Discourse Analysis and Translation}

The integration of discourse analysis in translation studies (TS) goes back to the functionalist theories of translation (Munday,2001, p. 73) The discourse analysis approach to TS applied Michael Halliday's register analysis model, which was mainly used to analyze the pragmatic functions of linguistic elements in both ST and TT, In his model called Systemic Functional Grammar, Halliday (1978) considers language as communication and uses the theoretical framework to uncover what situational factors determine the usage of linguistic elements (Halliday, 1978, p. 32). Based on Halliday's model, a new theoretical approach was created during 1990s as a separate branch of discourse analysis by Norman Fairclough called Critical Discourse Analysis (CDA). This framework is used to uncover the underlying ideological and power relations in the text. "CDA is a text-linguistic approach which mainly focuses on one language and one culture". However, in Translation Studies (TS) the CDA model has been applied not only on source text (ST), but it also focuses on target text (TT) as well. "CDA within TS has been mainly used to analyze political discourse due to the fact that the main aim of CDA is to uncover ideological and power structures in discourse" (Lande, 2010, pp. 2627).In translation studies, CDA has an optional role and is mainly used as an auxiliary tool to the existing methodological approaches to provide a comprehensive reflection on language and culture (Valdeón, 2007, p. 100).The research on CDA within TS is new and thus there is not any specific theoretical approach which serves as the backbone of this study. Hence, there have been debates whether CDA should be applied to TS (Schäffner, 2002, p. 53). The relation between TS and CDA has not been researched extensively. There are only a few linguists with a special interest in TS, who have contributed to this study with a few published works, e.g. Christina Schäffner (1997, 2002, 2003, 2004), Jeremy Munday (2001), Maria Calzade Pérez (2003) and Robert Valdeón (2007). The most influential work is that of Basil Hatim and Ian Mason $(1990,1997)$, who have published two books providing a very detailed insight into how the CDA model may be incorporated in translation theory.

\subsection{CDA ToolKits}

At the heart of any form of discourse analysis are the concepts that practitioners find most useful in doing close textual analysis, concepts that are most fruitful in allowing the analyst to pursue the stated aims and purposes of the analysis.

Since the main purpose of critical discourse analysis is to show how public discourse often serves the interests of powerful forces over those of the less privileged, analysts have generally focused on those aspects of language which often facilitate such abuses. (Huckin, 2007, p. 7)

This section details the concepts that we will use in doing our analysis.

\subsubsection{Lexicalization}

The Analysis of particular words used in news texts is "almost always the first stage of any text or discourse analysis. Words convey the imprint of society and of value judgments in particular- they convey connoted as well as denoted meanings" (Richardson, 2007, p. 47). As Van Dijk (1998) suggests opinions may be conventionalized and codified in lexicon (p. 205). Therefore, some words may be used to convey particular negative or positive meanings and implications about in-group and out-group members which may have an ideological basis (Martinez-Roldan and Malave, 2004, p. 165). Thus, Lexicalization or word choice is the major dimension of ideologically controlled meaning (Van Dijk, 1995, p. 259).

\subsubsection{Modality}

Modality as Richardson (2007) states refers to "judgments, comment and attitude in text and talk, and specifically the degree to which a speaker or writer is committed to the claim he or she is making" (p. 59). As Simpson (1993, p. 47) puts it, "modality refers broadly to a speaker's attitude towards, or opinion about, the truth of a proposition expressed by a sentence. It also extends to their attitude towards the situation or event described by a sentence". Modality is usually indicated "via the use of modal verbs (such as may, could, should, will and must), their negations (may not, couldn't, shouldn't, will not and must not) or through adverbs (certainly)". Richardson (2007) categorizes modality in two different types and believes that it may be expressed in two principal forms: truth modality and obligation (or duty) modality. Truth modality varies along a scale of options and obligatory modality which relates to the future events and, specifically, the degree to which the speaker/ writer believes that a certain course of action should be taken ((Richardson, 2007, pp. 59-60).

\subsubsection{Presupposition}

A presupposition is "a taken - for - granted, implicit claim embedded within the explicit meaning of a text or utterance" (Richardson, 2007, p. 63). Presuppositions are marked in a variety of ways in texts. Reah (2002) lists three linguistic structures common to presupposed meaning as follow: 
1) Certain words, such as change of state verbs (stop, begin, continue) or implicative verbs (manage, forget) invoke presupposed meaning in their very use: _stop' presupposes a movement or an action; 'forget' presupposes a great deal, including an attempt to remember.

2) The definite article ('the -) and possessive articles ('his/her-') trigger presuppositions. For example: 'the challenge facing the modern world ' not only presupposes a challenge exists by the also that a modern world does

3) Presuppositions are present in 'wh- questions', such as 'why' 'when', 'who', etc. so, a politician asked ' who is responsible for the poor state of the National Health Service? Is actually being asked two questions: the explicit request to name someone; and the presupposed question is someone responsible for the poor state of the National Health Service? Which remains implicit? (Reah, 2002, p. 106)

\subsubsection{Intertextuality}

Intertextuality is a concept often associated with postmodernism. The notion of intertextuality offers "a perspective of both reading and writing texts as a way of looking at a text's interactions with prior texts, writers, readers, and conventions" (Wang, 2006, p. 72). Thibault (1994) explains this perspective stating: "all texts, spoken and written, are constructed and have the meanings which text-users assign to them in and through their relations with other texts in some social formation" (p. 1751).

It is believed that Kristeva coined the term intertextuality on Bakhtin's work (Kristeva, 1986). According to Bakhtin (1986) "every text (or utterance) is dialogical in the sense that it gains its meaning in relation to other texts" (Bakhtin, as cited in Wang, 2006, p. 73). Kristeva (1981) points out that a given text is - a permutation of texts, an intertextuality: in the space of a given text, several utterances, taken from other texts, intersect and neutralize one other" (p. 36). As Wang (2006) states Scholars in different fields consider the notion of 'intertextuality' from different perspectives for different purposes. These scholars could be roughly categorized into two groups, namely Literary Semiotics and Critical Discourse Analysis.

Literary Semiotics: it includes the scholars like Kristeva (1981), Riffaterre (1978), Frow (1986), Culler (1981), Meinhof and Smith (2000) and Chandler (2005). Their main concern is with exploring the complex and heterogeneous nature of literary works by appropriating the concept of intertextuality.

Critical discourse analysis: it includes the scholars like Fairclough (1992a, b, c, 1995a, 1995b), Scollon (2004), Bazerman (1993, 2004), Devitt (1991), Beaugrande and Dressler (1981), and Lemke (1983, 1985, 1988a, 1988b, 1995a, 1995b). Their major concern is non-literary works. i.e. Intertextuality is perceived not only as a form through which texts are interrelated, but also as a social practice that involves particular socially regulated ways of producing and interpreting discourse (Fairclough, 1992a, 1992b, 1992c, 1995b) (Wang, 2006, pp. 73-74).

According to Fairclough (1992a, b, c, 1995b), intertextuality "points to how texts can transform prior texts and restructure existing conventions (genres, discourses) to generate new ones" (Fairclough, 1992b, p. 270). It is concerned with how texts are produced in relation to prior texts and how texts help to construct the existing conventions in producing new texts (Wang, 2006, p. 74).

\section{Methodology}

\subsection{Materials for analysis}

Uprisings in Arab countries began in 2010 with protests against Tunisian government and later spread across the Arab world, including Syria. Syrian Civil War began in 2011 with protests against President Bashar al-Assad's government. Hence, we have selected some news texts from Guardian, Reuters, the Independent and their Persian translations from Keyhan in order to elaborate the role of these agencies in the reportage of the news concerning Syria. Since the news providers transfer the news based on the ideological stand points of their news agencies. We will find that the Persian translations of the news in Keyhan are totally different from the English version of the news in Guardian, Reuters and the Independent. Therefore, this study on one hand will discuss the way in which the events and scenes are illustrated in source language news media On the other hand; it will also clarify how translation of news media paves the way for a biased interpretation in target language.

\subsection{Procedure}

Within the study, the English news texts and their Persian translations will be compared on the basis of Critical Discourse Analysis to uncover the impact of patronage's ideological insights in conveying the news. It should be mentioned that the present study has an interpretive approach with descriptive nature.

\section{Data Analysis and Discussion}

In this section the data will be analyzed based on the linguistic toolkits mentioned in the literature review section. Our analysis focuses on both sources (English version of the news and their translations) in order to reveal the role of patronage in the process of conveying the news.

\section{Sample 1.}

Source text: Guardian (August/29/2013)

Barak Obama's plans for air strikes against Syria were thrown into disarray on Thursday night after the British parliament unexpectedly rejected a motion designed to pave the way to authorising the UK's participation in military action. 
Target text: Keyhan (August/31/2013)

رأى منفى يارلمان انكليس برنامه هاى اوباما را به هم ريخت ومتحد وفادار امريكا واشنكتن را تتها كذاشت.

\section{Back-translation of target text:}

Negative vote of British parliament threw Obama's plans into disarray and the loyal ally of the US left Washington alone.

The English version of the news story implies that Obama's plans for military strike against Syria were unsuccessful. Reading the reportage critically, it gets clear that the Guardian editor states that their government respects the parliament. Wearing the lens of Intertextuality, he/she is intended to make the British readers of the news forget the wars in the Middle East their country had taken part. Turning to the translation, it is observed that the translator ironically tries to make the United States isolated in the eye of the readers. Reading critically we can find that the translation is biased. In other words, translation is intended to persuade the Persian readers that the only ally of the U.S. to attack Syria left them alone and it implies that without the participation of British Government the United States will not launch any strikes.

Lexically looking, by the choice of the adverb unexpectedly the ST implies that not only Barak Obama, but also the editorial board of the Guardian did not imagine that the British Parliament pass negative vote regarding to the military action against Syria but the translator has taken it for the granted.

\section{Sample 2.}

Source text: Reuters (September/8/2013)

"There has been no evidence that I used chemical weapons against my own people," CBS reported Assad said in an interview conducted in Damascus.

Target text: Keyhan (September/10/2013)

$$
\text { هيج سندى كه نشان دهد سوريه از سلاح شيميايى عليه مردم استفاده كرده وجود ندارد. }
$$

\section{Back-translation of target text:}

There has been no evidence that Syria used chemical weapons against people.

The original text is the direct quotation of Bashar Al-Assad the president of Syria. It talks about the chemical weapons which is said to be used against Syrians. He strongly claims that he has not used any chemical weapons against his people. Issuing the statements in this way makes the readers believe that what they are reading is a matter of fact; moreover, citing the exact words of an important official is a journalistic strategy to make the news impressive for the readers; hence, the translator has preferred to eliminate the quotation marks in this case the readers might think that the news agent has manipulated the news story.

Considering Van Dijk's (1998) notion of 'Ideological Square', the pronoun I in the original text tries to give a strong stance for Syrian president and show a good feature of him put in another way, the president of Syria who was thought to be a betrayer to his people attempts to erase this negative image.

Lexically looking, the choice of my own people in the original text carries a kind of presupposition for it tries to give a sense of legal power and authority Bashar-Al-Assad has over country and it contains a kind of sympathy towards Syrians. Looking at the translation it is observed that by the equivalence "مردم" the translator has not been able to transfer the impression existing in the original text.

\section{Sample 3.}

Source text: Reuters (September/8/2013)

Assad had a message for the American people that they should not get involved in another Middle Eastern conflict.

Target text: Keyhan (September/10/2013)

اسلد خطاب به مقامات امريكايى تأكيد كرد، بيام من به آمريكايى ها اين است كه ورود به هر كونه جنى و دركيرى در خاورميانه تجربه خوبى براى

\section{Back-translation of target text:}

Addressing American officials, Assad said my message to the Americans is that entering into any conflict in the Middle East is not a good experience for them.

The original text is a threatening statement which thwarts the United States from launching any military action against Syria. To put it in another way, it presupposes that Syria is different from the other countries in the Middle East which have been attacked. The translated text is also a threatening one which tries to remind the U.S. officials of the unpleasant experiences they have had from the previous wars in the Middle East.

Lexically looking, American people addressed by Assad, in the original text is replaced with "in the translation. The choice of this word presupposes that the editorial board of the Reuters attempts to warn people in the United States that the war with Syria is serious and they should inhibit it while by transferring with "as the addressees of Assad in the translation, it gets clear that the Persian newspaper attempts to persuade his/her audience that in comparison with the other countries in the Middle East which have been attacked by the U.S., Syria is more powerful and launching any military action against this country will have unpleasant consequences. 
The final important element to be discussed is related to the choice of the modal verb should not where it injects a severe sense of obligation and force to the whole meaning of the statement it gives without saying that modal verbs manifest the internal interests of the news reporter. Accordingly, the modal should not reflects that the reporter of the news supports the idea that like the previous wars in the middle east the war in Syria will be unpleasant if the U.S. attacks this country while the translator has taken it for the granted.

\section{Sample 4.}

Source text: The Independent (September/22/2013)

The Syrians have long claimed that a substantial amount of Soviet-made weaponry has made its way from Libya into the hands of rebels in the country's civil war with the help of Qatar.

Target text: Keyhan (September/23/2013)

بسيارى از تروريست هاى سورى اعتراف كرده اند با كمى قطر مقادير زيادى تسليحات نظامى از ليبى دريافت كرده اند كه ساخت اتحاد جماهير شوروى سابق بوده است.

\section{Back-translation of target text:}

Most of the Syrian terrorists have claimed that they have received a substantial amount of Soviet-made weaponry from Libya with the help of Qatar.

The original text notifies the readers of the role of neighboring countries in Syrian civil war. Through the principle of intertextuality, the editorial board of the Independent attempts to give legitimacy for possible strikes against Syria while the translation is biased.

Reading the target text we find that in line with ST the translation on one hand condemns Syrian neighboring countries which foment Syrian civil war, on the other hand he/she tries to acquit Syrian government from the war in the country.

Turning to the analysis of lexical elements, it is observed that the translator prefers to use"تروريست"for rebel in the target text. By the choice of this word, it gets clear that the editorial board of Persian newspaper is intended to illustrate that the Oppositions of Syrian government are brutal people who try to change the current ruling system and they do anything to get their goal while rebel means "a person who fights against people in authority" (Longman 2005, p. 1199) and this can be for different reasons either political economic etc.

\section{Sample 5.}

Source text: The Independent (September/22/2013)

There is no doubt that Syria has a substantial amount of chemical weaponry armoury. Nor that Syrian stockpiles contain large amount of Sarin gas 122mmmissiles. But if the Russians have indeed been able to identify the specific missile markings on fragments found in Ghouta-and if these are from munitions never exported to Syria-the Assad regime will boast its innocence has been proven.

Target text: Keyhan (September/23/2013)

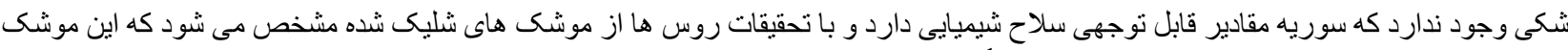

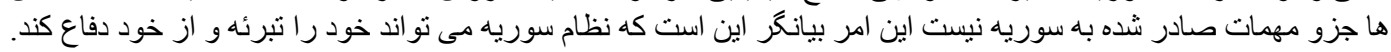

Back-translation of target text:

There is no doubt that Syria has a substantial amount of chemical weaponry armory. Russia's investigations from the launched missiles illustrates that the missiles are not among the ammunitions exported to Syria. This indicates that Syrian ruling system can acquit itself.

Comparing the two texts, we find that they are differently delivered. Regarding to the original text, it is observed that the news provider puts the reader in dilemma while the translation is an informative one eliminating some parts of ST in the target text and manipulating the other parts attempts to give a good image from Syrian Government.

Looking through syntactical lens, the use of If clause -If the Russians have indeed been able to identify the specific missiles marketing on fragments found $n$ Ghouta - puts the reader in dilemma in other words, it presupposes that if it is proven that Syria has used specific missiles in Ghouta and the missiles are from the munitions exported to this country the military strike will be inevitable

Taking lexical aspects of the original text into account, the word regime implies a negative meaning "a method or system of government especially one that has not been elected in a fair way" (Oxford, 1948, p.1273). The way of titling Syrian ruling system in this way gives a negative image from Syrian government and it implies that the editorial board of the Independent opposes Syrian government. By the choice of "نظام سوريه as an equivalence for Assad Regime the translator gives a positive image from Syrian ruling system and persuades her/his audience to believe that the people in authority are legally elected.

Intertextual analysis is another tool to extract ideological traces placed in the news texts. Wearing the lens of intertextual analysis, It is observed that by the phrase -Nor that Syrian stockpiles contain large amount of Sarin gas $122 \mathrm{~mm}$ missiles- the news provider attempts to remind the reader of the sarin gas missile attack that killed around 1400 Syrian in the suburb of Ghouta on 21 August and it is intended to accuse Syrian government for the attack; however, by ignoring the phrase in the target text, the translator does not want to damage the image of Syrian government in the eye of her/his readers. 


\section{Conclusion}

Nowadays media are the main source to provide people with information. However, the news media is considered to be widely biased. A survey by the American Society of Newspaper Editors (ASNE (1999)) revealed that 78 percent of the public believed that there was bias in news reporting. In Barron's paper media bias is defined "relative to the truth." The American Society of Newspaper Editors (ASNE) found that some people believe that media bias is "favorism of a particular social or political group", which is closer to the meaning of media bias in this paper. Under this definition journalists could report the truth but favor one particular political party in his selection of information to be reported (Chiang, 2007, p. 3)

In sum, we can conclude that "news carries a unique signifying power, a power to represent events in part (Joye, 2010, p. 586). Besides, Fairclough' s (1995a) "unveiling of opaque ideological relations between discourse and socio-cultural practices" and Lefevere's consideration of translation as rewriting which is carried out "within the ideological constraints of patronage" (Lefevere, 1992b, p. 7), we conclude that power relations and ideological stand points of the news providers highly affect the process of news production in translation. Moreover, through the analysis of the news excerpts, we found that news mediated translations are ideological or biased.

\section{References}

American Association of Newspaper Editors. (1999). Examining our Credibility: Examining Credibility, Explaining Ourselves. Reston, Va. Retrieved from http://www.asne.org.

Bakhtin, M. M. (1986). The problem of speech genres. In C. Emerson \& M. Holquist (Eds.), Speech genres and other late essays. Austin: University of Texas Press.

Bazerman, C. (1993). Intertextual self-fashion: Gould and Lewontin's representation of the literature. In J. Selzer (Ed.), Understanding scientific prose. Madison: University of Wisconsin Press.

Bazerman, C. (2004). Intertextuality: How texts rely on other texts. In C. Bazerman \& P. Prior (Eds.), What writing does and how it does it: An introduction to analyzing texts and textual practices (pp. 83-96). Mahwah, NJ: Lawrence Erlbaum Associates, Publishers.

Beaugrande, R. D., \& Dressler, W. U., (1981).Introduction to text linguistics. London: Longman.

Calzada Perez, M. (2003). Interduction. In M. Calzada Perez, Apropos of ideology (pp.1-22). Manchester: St. Jerome.

Chandler, D. (2005). Intertextuality in semiotics for beginners. Retrieved May 25, 2005, from http://www.aber..uk/media/Documents/S4B/sem09.html.

Chiang, C. F. (2007).Sources of Media Bias Available online. Retrieved January 15, 2012, from http://homepage.ntu.edu.tw/-chungfang/Bias.pdf.

Croteau, D., \& Hoynes, W. (2003).Media and ideology. In M. Seawell \& A. Carter \& S. Robinson \& G. Dickens (Eds.), Media/society: Industries, images and audiences (pp.159-185). Thousand Oaks, Calif: Pine Forge Press.

Culler, J. (1981).The pursuit of signs: Semiotics, literature, deconstruction. London: Routledge and Kegan Paul.

Darwish, A. (2006). Translating the news reframing constructed realities. Translation Watch Quarterly, 2(1), 52-77.

Devitt, A. J. (1991). Intertextuality in tax accounting: generic, referential, and functional. In C. Bazerman\& J. Paradis (Eds.), Textual dynamics of the professions: Historical and contemporary studies of writing in professional community. Madison: University of Wisconsin Press.

Fairclough, N. (1992a). Discourse and social change. Oxford: Polity Press.

Fairclough, N. (1992b). Discourse and text: linguistic and Intertextual analysis within discourse analysis. Discourse and Society, 3(2), 193-217.

Fairclough, N. (1992c). Intertextuality in critical discourse analysis. Linguistics and Education, 4, 269-293.

Fairclough, N. (1995a). Critical Discourse Analysis: The Critical Study of Language. London: Longman.

Fairclough, N. (1995b). Media Discourse. London: Edward Arnold.

Fairclough, N., \& Wodak, R. (1997).Critical Discourse Analysis. Teun A. van Dijk, (ed.), Discourse as Social Interaction, 2, 258-84. London: Sage.

Fawcett, P. (1998). Ideology and Translation. In M. Baker, ed. Routledge Encyclopedia of Translation Studies. London, Routledge, 106-110.

Fiske J.(1994) Media Matters: Everyday Culture and Political Change. Minneapolis: University of Minnesot press.

Frow, J. (1986).Marxism and literary history. Oxford: Blackwell.

Hallahan, K. (1997). The consequences of mass communication: Cultural and Critical Perspectives on Mass Media and Society. New York: McGraw-Hill.

Halliday, M.A.K. (1978). Language as social semiotic: The social interpretation of language and meaning. London: Eward Arnold Publishers.

Hatim, B., \& Mason, I. (1997).The Translator as Communicator. London: Routledge. 
Hatim, B., \& Mason, I. (1990).The Discourse and the Translator. London and New York: Longman.

Hatim, B., \& Munday, J. (2004).Translation: An advanced resource book. London and New York: Routledge.

Huckin, T. (2002).Critical discourse analysis and the discourse of condescension. Barton, E. Stygall, G Discourse studies in composition. Cresskill, NJ: Hampton, 155-176.

Joye, S. (2010). News discourse on distant suffering: A Critical Discourse Analysis of the 2003 SARS outbreak. Discourse \& Society, 21(5), 586-601.

Karoubi, B. (2005). Ideology and Translation with a concluding point on translation teaching. Retrieved February 6 , 2014 from: http://www.translationdirectory.com article 233.htm.

Kristeva, J. (1981). Word, dialogue and novel. In L. S. Roudiez (Ed.), Desire in language: A semiotic approach to literature and art. Oxford: Blackwell.

Kristeva, J. (1986). Word, dialogue and novel. In T. Moi (Ed.), The Kristeva Reader. Oxford: Blackwell.

Lande, I. (2010). The Role of Critical Discourse Analysis in the Translation of Political Texts. (Master's Thesis, Aarhus University).

Lefevere, A. (1992a). Translation. History and Culture: A Source Book. London /New York: Routledge.

Lefevere, A. (1992b). Translation. Rewriting and the Manipulation of Literary Fame. London/New York: Routledge. Lemke, J. L. (1983). Thematic analysis: Systems, structures, and strategies. Semiotic Enquiry, 3(2), 159-187.

Lemke, J. L. (1985). Ideology, intertextuality, and the notion of register. In J. D. Benson W. S. Greaves (Eds.), Systemic Perspectives on Discourse, Volume 1. Norwood, NJ: Ablex Publishing Corporation.

Lemke, J. L. (1988a). Discourse in conflict: Heteroglossia and text semantics. In J. D. Benson \& W. S. Greaves (Eds.), Systemic Functional Approaches to Discourse. Norwood, NJ: Ablex.

Lemke, J. L. (1988b). Text structure and text semantics. In R. Veltman \& E. Steiner (Eds.), Pragmatics, Discourse, and Text. London: Pinter.

Lemke, J. L. (1995a). Intertextuality and text semantics. In P. Fries \& M. Gregory (Eds.), Discourse in society: Systemic functional perspectives: Meaning and choice in language: Studies for Michael Halliday. Norwood, NJ: Ablex Publishing Corporation.

Lemke, J. L. (1995b). Textual politics: Discourse and social dynamics. London: Taylor and Francis Ltd.

Longman, P. (2005). Longman Advanced American Dictionary (3rded.). London: Longman.

Malkawi, R. (2012). The Ideological Stamp: Translation of Political Discourse in News Media. (Master's thesis). Retrieved from https://dspace.aus.edu.

Martinez-Roldan, C.M., \& Malave, G. (2004). Language Ideologies Mediating Literacy and Identity in Bilingua Contexts. Journal of Early Childhood Literacy, 4(2), 155- 80.

Meinhof, U. H., \& Smith, J. (Eds.). (2000). Intertextuality and the media: From genre to everyday life. Manchester and New York: Manchester University Press.

Munday, J. (2001). Introducing Translation Studies: Theories and Applications. London and New York: Routledge.

Oxford Advanced Learner's Dictionary ( $7^{\text {th }}$ ed.). (1948). Oxford: Oxford University Press.

Pym, A. (2010). Exploring Translation Theories. London and New York: Routledge.

Pérez. C. M. (2003) Apropos Ideology. Translation Studies on Ideology - Ideologies in Translation Studies. Manchester: St. Jerome.

Reah, D. (2002).The Language of Newspapers. London: Routledge.

Richardson, J. (2007). Analyzing newspapers: an approach from critical discourse analysis. Basingstoke: Palgrave.

Riffaterre, M. (1978).Semiotics of poetry. Bloomington, IN: Indiana University Press.

Schäffner, C. (1997). Strategies of Translating Political Texts, Benjamins Publishing Company, 26, 119-144.

Schäffner, C. (2002).The Role of Discourse Analysis for Translation and in Translation Training.UK: Multilingual Matters Ltd.

Schäffner, C. (2003). Third Ways and New Centers: Ideological Unity or Difference? In M. Calzade-Pérezed. Apropos of Ideology: Translation Studies on Ideology - Ideology in Translation Studies (pp. 23-41). Manchester: St. Jerome.

Schäffner, C. (2004). Political discourse analysis from the point of view of translation studies. Journal of Language and Politics, 3(1), 117-150.

Scollon, R. (2004). Intertextuality across communities of practice: Academics, journalism and advertising. In C.L. Moder\& A. Martinovic-Zic (Eds.), Discourse across language and cultures (pp.149-176). Amsterdam/Philadelphia: John Benjamins Publishing Company.

Shuping, R. (2013). Translation as Rewriting. International Journal of Humanities and Social Science, 3(18), 56- 
Simpson, P. (1993). Language, ideology and point of view. London: Routledge. Retrieved March 2, 2011 from http://books.google.com/.

Steiner, G. (2004). Translation as condition humane. In Harald Kittel and Armin Paul Frank (eds), Übersetzung: ein Internationales Handbuch z ur Übersetzungsforschung. 1. Teilband = Translation: an international encyclopedia of translation studies. Volume 1= Traduction: encyclopédie Internationale de la recherche sur latraduction (pp. 1-11). Berlin and New York: Walter de Gryuter.

Thibault, P. J. (1994). Intertextuality. In R. E. Asher (Ed.), The Encyclopedia of language and linguistics, Vol. 4.Oxford: Pergamon Press.

Valdeon, A., R. (2007) Ideological Independence or Negative Mediation: BBC Mundo and CNN en Español(translated) Reporting of Madrid's Terrorist Attacks. Translating and Interpreting Conflict. Amsterdam/New York: Rodopi, 99198.

Van Dijk, T. A. (1993).Principles of Discourse Analysis. Discourse \& Society, 4(2), 149-28.

Van Dijk, T. A. (1995).The Mass Media Today: Discourse of Domination or Diversity? Retrieved January15, 2012, from http://www.starfirerapture.com/LavJangHandoutfinal.pdf.

Van Dijk, T.A. (1998). Opinions and Ideologies in the Press. In Bell, Allan \& Peter Garrett (Eds.), Approaches to Media Discourse. Oxford: Blackwell.

Van Dijk, T.A. (2001). Critical Discourse Analysis. In D. Tannen, D. Schiffrin, \& H. Hamilton (Eds.), Handbook of Discourse Analysis. Oxford: Blackwell.

Wang, W. (2006).Newspaper commentaries on terrorism in China and Australia: A contrastive genre study. (Doctoral dissertation, The University of Sydney).

Zhang, M. (2012). Translation Manipulated by Ideology and Poetics--A Case Study of The Jade Mountain. Theory and Practice in Language Studies, 2(4). 